\title{
Effect of Killing Liquids on the Larval Length of forensically important Lucilia sericata
}

\section{Öldürme Sıvılarının Adli Önemi olan Lucilia sericata’nın Larva Uzunluğuna Etkisi}

\author{
Halide Nihal Açıkgözl , Ali Açıkgöz² \\ ${ }^{1}$ Ankara University, Institute of Forensic Sciences, Ankara \\ ${ }^{2}$ Turkish Republic of Health Minister, Havacılar Family Health Center, Ankara
}

\begin{abstract}
Objective: Forensic entomological practices rely upon accurate larval identification and measurement of larval length, for the estimation of post-mortem intervals. The methods used for killing larvae may affect the length of larvae. In the autopsy hall, corpses which are contain entomological remains have been washed with grape vinegar. Besides, while collecting and killing the larvae on corpses, crime scene teams use ethanol $70 \%$ because it is practical.

The aim of this study was to determine which of hot water $\left(90^{\circ} \mathrm{C}\right)$, cold vinegar and cold ethanol $96 \%$ method, preserved the best the length of larvae.

Materials and Methods: To achieve this aim, third instar larvae which are reared on $200 \mathrm{~g}$ of veal meat were killed using hot water, cold vinegar and cold ethanol. Before killing and after killing the maggots, their length was measured. To determine the difference between the groups to be compared ANOVA test, to reliability and validity analyses Kruskal-Wallis and whether there was any difference between the groups were made with Tukey's Honestly Significant Difference (Tukey's HSD)

Results and Conclusion: Hot water was found to preserve the length of the larvae more accurately than cold vinegar and ethanol. Forensic medicine experts and crime scene teams should kill the larvae collected from a corpse for entomological examination using hot water, dry them in paper towels and preserve them in $96 \%$ ethanol and then send them to a forensic entomologist.

Keywords: Forensic Entomology; Lucilia Sericata; Postmortem Interval; Larval Killing Methods.
\end{abstract}

\section{Introduction}

Forensic entomology is the application of insect and other arthropods biology to the suspicious death enquiries (1-5). Forensic scientists have become more interested in forensic entomology as they take advantage of

Corresponding Author: Halide Nihal Açıkgöz, PhD, Forensic Biology

Ankara University, Institute of Forensic Sciences, Ankara

E-mail:nacikgoz@yahoo.com

${ }^{\star}$ Some part of this study was presented as a poster at 5th Meeting of

The European Association for Forensic Entomology in Brussels, 2007.

Arrived: 15.11.2017 Revised: 15.12.2017 Accepted: 21.12.2017

\section{Özet}

Giriş: Adli entomolojik uygulamalar, ölüm sonrası geçen sürenin tahmini için larva uzunluğunun doğru ölçülmesine ve doğru larval identifikasyona dayanır. Larvaları öldürmek için kullanılan yöntemler larvaların boyunu etkileyebilir. Otopsi salonunda, entomolojik kalıntılar içeren cesetler üzüm sirkesi ile yıkanmaktadır. Ayrıca, cesetler üzerindeki larvaları toplarken ve öldürürken olay yeri ekipleri pratik olduğu için \%70'lik etil alkol kullanırlar.

$\mathrm{Bu}$ çalışmanın amacı sıcak su $\left(90^{\circ} \mathrm{C}\right)$, soğuk sirke veya soğuk etil alkol yönteminden hangisinin larva uzunluğunu en iyi koruduğunu belirlemektir.

Gereç ve Yöntem: Bu amaca ulaşmak için, $200 \mathrm{~g}$ dana etinde yetiştirilen üçüncü evredeki larvalar sıcak su, soğuk sirke ve soğuk etil alkol kullanılarak öldürüldü. Öldürmeden önce ve öldürdükten sonra, larvaların boyları ölçüldü. Karşılaştırılacak gruplar arasındaki farkı belirlemek için ANOVA testi, güvenilirlik ve geçerlik analizleri için Kruskal-Wallis ve gruplar arasında bir fark olup olmadığını belirlemek için Tukey's Honestly Significant Difference (Tukey's HSD) testi uyguland.

Bulgular ve Sonuç: Sıcak suyun larvaların uzunluğunu soğuk sirke ve etil alkolden daha doğru olarak koruduğu bulundu. Adli tıp uzmanlarınca ve olay yeri inceleme ekibince, adli entomolojik inceleme için ceset üzerinden alınan larvalar, kaynar su ile öldürülüp ardından kâğıt havlu ile kurulandıktan sonra \%96'lık etil alkol içerisinde fikse edilerek adli entomoloğa gönderilmelidir.

Anahtar Kelimeler: Adli Entomoloji; Lucilia Sericata; Postmortem İnterval; Larva Öldürme Yöntemleri.

entomological evidence to determine the time and cause of death (6).

It has been reported using ethanol to kill and preserve larvae causes their shrinkage and prevents accurate estimation of larval length and morphological features (7-9). However, it has been noted that compared to ethanol, hot water (HW) is reliable in estimation of larval length and does not impair morphological features of larvae (7).

In Turkey, as a general rule, forensic investigation teams use ethanol 70\% (Merck) to kill and preserve larvae collected from crime scenes and corpses. Following forensic examinations and before autopsies, some doctors 
of forensic medicine use grape vinegar (4-5\%) to kill entomological remains on corpses. Effects of grape vinegar used to remove insects from the corpses on larval length are not known. Thus, the aim of this study was to determine which of ethanol, HW and grape vinegar preserved larval length the best.

\section{Materials and Methods}

Veal beef ( $200 \mathrm{~g})$ was put in a basic meat bait trap and hung on the campus of the University of Ankara, Forensic Medicine Institute in July. The study site's altitude is $850 \mathrm{~m}$ and its coordinates are $39^{\circ} 56^{\prime} 01.57 \phi^{\prime} \mathrm{N}$; $32^{\circ} 53^{\prime} 06.43 \phi \notin \mathrm{E}$. After the insects had laid their eggs on the beef, larval development was checked every two hours during the day time (starting from 9 am to $5 \mathrm{pm}$ ). The larvae, which became 3 instar on the fourth day, were taken to the laboratory and their length was measured while alive. This procedure was difficult as they were stretching and shrinking quickly. To prevent this, ten larvae at a time were treated by chloroform during 10 seconds in order to immobilize them to measure their length. Identifications of species were made using the key described by Smith (10) and apochromatic 1x objective and 8:1 zoom lens system in the light of the relevant literature. Lucilia sericata (Meigen, 1826) (Diptera: Calliphoridae) larvae were included in the study. Then, 50 larvae were placed into each jar; the date and the liquid used to kill the larvae were noted on the jars. Hot water (HW) was added very quickly to one jar. Cold vinegar (4$5 \%$ ) was added to another jar and cold ethanol (ethanol $96 \%, \mathrm{CHOH}, \mathrm{MERCK}$ ) was added to the last jar include larvae. One hour later, the length of the larvae exposed to HW, exposed to vinegar and exposed to ethanol were measured using a stereo zoom microscope. Larval length was both noted on the tubes and recorded in Microsoft Office Excel 2007. Hot water, vinegar and ethanol, were poured out and the larvae whose lengths were measured were washed with clean water. Last, ethyl ethanol $96 \%$ and glycerin (19 part ethanol: 1 part glycerin) were added to all the tubes and preserved. The reliability and validity analyses were made with Kruskal-Wallis and Tukey's Honestly Significant Difference (Tukey's HSD).

\section{Results and Discussion}

In this presented study, we compared the effect of HW, vinegar and ethanol, used to kill Lucilia sericata larvae, on their morphological structures. After they were exposed to HW $\left(90^{\circ} \mathrm{C}\right)$, all the 3 instar Lucilia sericata larvae died immediately. Maggots killed by HW were softer and straighter than those killed by vinegar and ethanol and the ones killed by vinegar were softer and less curled than those killed by ethanol. Maggots killed by ethanol were harder and more curled. The larvae killed by HW were those whose lengths were the easiest to be measured. As morphological features of the larvae were not affected by HW temperature. This shows that this killing method preserved the best their length. Our results are supported by those of Amendt, et al. (7) who stated that HW below boiling temperature $\left(>80^{\circ} \mathrm{C}\right)$ was the best method to kill maggots.

\section{Statistical analysis}

The average length before and after killing the larvae of $L$. sericata are presented in Table 1 .

Table 1. Comparison of the average length of $L$. sericata larvae before and after killing.

\begin{tabular}{|c|c|c|c|}
\hline \multirow{2}{*}{$\mathbf{c m}$} & HW & Vinegar & Ethanol \\
\cline { 2 - 4 } & \multicolumn{3}{|c|}{$\mathbf{n = 5 0}$} \\
\hline $\begin{array}{c}\text { Length } \\
\text { before killing }\end{array}$ & $1,40 \pm 0,11$ & $1,24 \pm 0,10$ & $1,20 \pm 0,06$ \\
\hline $\begin{array}{c}\text { Length after } \\
\text { killing }\end{array}$ & $1,50 \pm 0,13$ & $1,40 \pm 0,11$ & $1,40 \pm 0,15$ \\
\hline
\end{tabular}

An ANOVA test was conducted to determine the difference between the groups to be compared. When we look at the difference between the groups, it is noted that the killing method used has a significant difference in terms of the effect on the length of the larvae. ( $p=$ 0.002). Tukey's HSD test was used to determine if there was any difference between the groups, as we found that the methods differed in their effect on larval length. As a result of Tukey's HSD test; there was an increase in the post-killing posture in all the three groups compared to the pre-killing posture. These augmentations were found to be $0.08 \mathrm{~cm}(\mathrm{p}=0.001)$ for the larvae killed in hot water, $0.19 \mathrm{~cm}(\mathrm{p}=0.000)$ for the larvae killed in ethanol and $0.20 \mathrm{~cm}(\mathrm{p}=0.000)$ for the maggots killed in vinegar.

Kruskal-Wallis variance analysis was performed to determine the effects of the methods of killing used on larval length. Statistically significant differences were found when comparing the differences between the groups according to the test results. Extent of height in larvae killed by hot water was lower than vinegar and ethanol $(p=0.002)$. There is a significant difference in the mean length of larvae between the ones exposed to HW and those exposed to ethanol $(\mathrm{p}<0.05)$. Whereas, there is no significant difference between larvae exposed to vinegar and the ones exposed to ethanol ( $p>0.05)$.

The applied statistic tests show that in each method, height extension is seen. However, in order to minimize the effect of larval length on morphological identification, 
HW killing method is found to be safer. Determination of PMI is based on the identification of larval species and estimation of the age of the oldest larvae found on a corpse $(11,12)$. Therefore, maggot length is crucial data for estimation of post-mortem interval (PMI) (13).

\section{Morphological changes}

The color of the larvae exposed to ethanol started to get dark in twenty minutes. The larvae that remained alive for 60 minutes started to become dark in color in their posterior side, and their head and the 3 and 4 thorax segments became darker. The whole body of all the larvae that died 150 minutes after being exposed to ethanol became darker. Amendt, et al. (7) reported that putrefaction caused larvae to become dark. The authors also noted that larvae exposed to ethanol shrink while they are alive. This shrinkage has a negative effect on the estimation of the larval length and recognition of their morphological features. It was observed that putrefaction caused by ethanol was noted only in living larvae, which were exposed to pure ethanol. The literature supports our results. Rosilawati, et al. (14) reported that killing maggots in $80^{\circ} \mathrm{C}$ or $90^{\circ} \mathrm{C}$ hot water caused minimum changes in larval length, and ensured the protection of their creamy color, turgidity, and curvature. Results of this present study are in agreement with the literature. Şaki and Özer (15) used hot ethanol $70 \%$ to kill larvae. Richards, et al. (16), in their studies using Lucilia sericata and Calliphora vomitoria maggots, also recommended that the larvae should be killed with HW (8).

\section{Conclusion}

Hot water had a less significant effect on larval length than ethanol and vinegar and did not change morphological features.

It can be suggested that larvae should be killed with HW while they are collected from crime scenes in order to estimate their lengths accurately and to preserve their morphological features. Larval length is significant data for estimation of PMI

In the absence of morphological changes, the larvae taken from hot water should be dried and then preserved in $96 \%$ ethanol (17). Water entering maggots causes the dilution of ethanol and the darkening of the anterior part.

After examinations of dead bodies and before autopsies, entomological evidence collected from various parts of the body should be put into separate tubes, labeled, killed with HW, dried with paper napkin and preserved in $96 \%$ ethanol and immediately sent to an entomologist. Besides, forensic specialists who perform internal and external examinations of the body should be in close contact with forensic entomologists, which will allow evaluation of the body in terms of insect evidence.

\section{References}

1. Amendt J, Krettek R, Zehner R. . Naturwissenschaften. 2004, 91, (2), 51-65. doi: 10.1007/s00114-003-0493-5

2. Erzinclioglu Z.. Clin. Med. 2003, 3, (1), 74-76.

3. Carvalho RP, Azevedo WTA, Figueiredo AL, Lessa CSS, Aguiar VM. Dipterofauna Associated With Rat Carcasses in the Atlantic Forest, Southeastern Brazil. J. Med. Entomol. 2017, 54, (6), 1498-1509. doi: 10.1093/jme/tjx118

4. Ahmad A, Ahmad A. A preliminary study on the decomposition and dipteran associated with exposed carcasses in an Oil Palm Plantation in Bandar Baharu, Kedah, Malaysia. Trop. Biomed. 2009, 26, (1), 1-10.

5. Joseph I, Mathew D, Sathyan P, Vargheese G. The use of insects in forensic investigations: An overview on the scope of forensic entomology. J. Forensic Dent. Sci. 2011, 3, (2), 89-91. doi: 10.4103/0975-1475.92154

6. Benecke M. Arthropods and corpses. In Tsokos M, Ed. Forensic Pathology Reviews, Humana Press: 2005; Vol. 2, pp 207-240.

7. Amendt J, Campobasso C, Gaudry E, Reiter C, Le Blanc $\mathrm{H}$, Hall M. Best practice in forensic entomology--standards and guidelines. Int. J. Legal Med. 2007, 121, (2), 90-104. doi: 10.1007/s00414-006-0086-x

8. Adams Z, Hall M. Methods used for the killing and preservation of blowfly larvae, and their effect on post-mortem larval length. Forensic Sci. Int. 2003, 138, (1-3), 50-61. doi: 10.1016/j.forsciint.2003.08.010

9. Tantawi T, Greenberg B. The effect of killing and preservative solutions on estimates of maggot age in forensic cases. J. Forensic Sci. 1993, 38, (3), 702-707. doi: 10.1520/ JFS13458J

10. Smith K. A manual of forensic entomology. University Printing House: Oxford, 1986; p 1-102.

11. Anderson G. Minimum and maximum development rates of some forensically important Calliphoridae (Diptera). J For Sci. 2000, 45, (4), 824-832. doi: 10.1520/JFS14778J

12. Grassberger M, Reiter C. Effect of temperature on development of the forensically important holarctic blow fly Protophormia terraenovae (Robineau-Desvoidy) (Diptera: Calliphoridae). Forensic Sci. Int. 2002, 128, (3), 177-182. doi: 10.1016/S0379-0738(02)00199-8

13. Gennard D. Forensic entomologye: An inroduction. John Wiley \& Sons Ltd: England, 2007.

14. Rosilawati R, Baharudin O, Syamsa R, Lee H, Nazni W. Effects of preservatives and killing methods on morphological features of a forensic fly, Chrysomya megacephala (Fabricius, 1794) larva. Trop Biomed. 2014, 31, (4), 785-791.

15. Şaki C, Özer E. Morphology and Develepmont of Several External Myiasis Larvae Recorded in Elazığ. Turk J Vet Anim Sci. 1999, 23, 723-731.

16. Richards CS, Rowlinson CC, Hall MJR. Effects of storage temperature on the change in size of Calliphora vicina larvae during preservation in $80 \%$ ethanol. Int. J. Legal Med. 2013, 127, (1), 231-241. doi: 10.1007/s00414-012-0683-9

17. Açıkgöz HN. Olay Yerinden Ekolojik ve Entomolojik Verilerin Toplanmas1. Jandarma Dergisi. 2013:135;26-33. 